University of Nebraska - Lincoln

DigitalCommons@University of Nebraska - Lincoln

March 1980

\title{
An Assessment Dependent upon Technology
}

F. Gregory Hayden

University of Nebraska - Lincoln, ghayden1@unl.edu

Follow this and additional works at: https://digitalcommons.unl.edu/cbafacpub

Part of the Business Commons

Hayden, F. Gregory, "An Assessment Dependent upon Technology" (1980). College of Business Faculty Publications. 6.

https://digitalcommons.unl.edu/cbafacpub/6

This Article is brought to you for free and open access by the Business, College of at DigitalCommons@University of Nebraska - Lincoln. It has been accepted for inclusion in College of Business Faculty Publications by an authorized administrator of DigitalCommons@University of Nebraska - Lincoln. 
Published in Journal of Economic Issues, 14:1 (March 1980), pp. 211225.

Published and copyright (C) 1980 by the Association for Evolutionary Economics. 


\title{
An Assessment Dependent upon Technology
}

\begin{abstract}
"Technology and Economic Dependency: An Institutional Assessment," by Thomas De Gregori, deserves serious consideration because it reaches to the heart of a conflict in holistic economic systems analysis and planning. The major issue in the article revolves around divergent views regarding technology. One is that technology should dominate society by being made the primary determinant of policy evaluation criteria. Another view is that technology should be treated as a system entity, albeit a powerful one, which must be evaluated along with others. De Gregori's conclusions are based on the first view.

This comment will consider five aspects of De Gregori's article. First, there are statements unsubstantiated by evidence. This will be demonstrated by offering contrary evidence regarding his remarks on urbanization, nutrition delivery systems, and big dams. Second, the views of appropriate technology proponents are misrepresented. Third, many of the terms used beg for definitions. These will be indicated below by the insertion of bracketed statements. Fourth, De Gregori's conclusions are based on a teleological tautology. Finally, Clarence Ayres's institutional theory is misrepresented.
\end{abstract}

\section{Urbanization}

Let us begin by reviewing part of De Gregori's first paragraph: "We adapt our lives to our technology. Population growth and concentration in urban centers have been elements in this continuous adjustment. This process is largely irreversible without entailing some catastrophe." ${ }^{2}$ We do adapt our lives to our technology, but to be more correct, we adapt our lives to a host of cultural, social, technological, and ecological entities, including ecological degradation; conversely, we adapt those entities. If we can adapt them, De Gregori's sentence is incorrect, because urban growth mainly has been a result of government policies which have emptied rural areas rather than because of some deterministic adjustment.

In the United States, various government programs-ranging from the concentration of research centers to the payment of farm subsidiesencourage migration to urban areas. Technology certainly has been involved in rural enclosure, but government policy has guided technological selection and influenced the resulting social change. Usually, people have been pushed off rather than enticed from the land. As F. Ray Marshall 
points out, half of those who changed from farm to nonfarm jobs suffered a decrease in income. ${ }^{3}$

Rural enclosure and consequent urban concentration have been accomplished by paying the majority of government subsidies to rich farmers ${ }^{4}$; paying more subsidies the more acreage left idle ${ }^{\tilde{5}}$; paying nothing to labor idled with the land ${ }^{6}$; paying the highest price subsidies to those with the greatest production ${ }^{\overline{7}}$; subsidizing capital equipment but not labor ${ }^{8}$; providing large research and irrigation projects to complement big producers' technology ${ }^{9}$; allowing subsidy programs to be capitalized into the price of farmland so that only the rich can afford the land ${ }^{10}$; providing government crop insurance and loan guarantees to remove the risk for absentee owners $^{11}$; and providing special tax loopholes to protect large incomes from taxation, such that 80 percent of farm tax "losses" accrue to those in the ten largest metropolitan areas. ${ }^{12}$ "Agribusiness interests have been able to perpetuate their control over the system through a constellation of political and economic powers extending from Congress to the local sheriff's office." $1:$

As people are driven from the farms, rural towns have decreasing business sales, employment, income, and property valuations, and taxes become inadequate to support public services. ${ }^{14}$ In addition, national and state government has failed to provide adequate public services to rural areas. ${ }^{15}$ The final result has been pervasive societal disintegration and mass migration to urban areas in an attempt by rural people to avoid personal decay. ${ }^{16}$

The "concentration in urban centers" has not been the result of adapting our lives to technology. ${ }^{17}$ Therefore, since the government is not bound by a deterministic technological adaptation, government policy could be reversed "without entailing some catastrophe."18

\section{Nutrition Delivery System}

The next three sentences of De Gregori's first paragraph are also very misleading.

We have enough difficulty in feeding the more than three billion and soon to be four billion people on this globe, using current technology and the scattered remnants of earlier technologies. Imagine the absurdity of attempting to carry out this endeavor relying solely on hunting and gathering. Or, for that matter, consider the impossibility of meeting today's nutritional needs solely with agricultural practices that predate the Industrial Revolution. ${ }^{19}$ 
This statement, similar to the advertisements of United Technologies Corporation, emphasizes the benefits of the modern international agribusiness technostructure for providing nutritional needs. This is the same technostructure which destroys cities by overloading them with displaced persons ${ }^{20}$; destroys rural communities and their social services because there are not enough people to support them ${ }^{21}$; destroys topsoil and water supplies $^{22}$; poisons ground and surface water supplies with chemicals, pesticides, and fertilizers"3; augments desertification ${ }^{24}$; destroys soil humus and porosity, which means less water retention, which means that compacted soil needs larger tractors which further compact soil ${ }^{25}$; leaches nutrients from and adds salts to the soil through irrigation ${ }^{26}$; uses more energy than it produces ${ }^{27}$; causes worker sterility in the fertilizer factories ${ }^{28}$; creates health problems for farmers who apply the toxic fertilizers, pesticides, and herbicides ${ }^{29}$; uses fertilizers which prevent plants from absorbing nutrients necessary for human health ${ }^{30}$; fills the food chain with carcinogenic pesticides, herbicide growth hormones, and antibiotics ${ }^{31}$; creates an expensive and unnecessary transportation system ${ }^{32}$; diverts millions of acres each year in Third World countries to nonfood production ${ }^{33}$; processes the nutrients out of what food is produced with the profits being greater, the greater the amount of processing ${ }^{34}$; and fills the processed product with carcinogenic preservatives, refined sugars, salt, and artificial colors. ${ }^{35}$ Dr. Carlton Fredericks offers the example of egg substitutes as the typical final human food product in the United States. They are

made from corn oil, egg white, nonfat dry milk, emulsifiers, gums, preservatives, artificial flavor, aluminum sulfate, artificial color, iron phosphate, and three added vitamins, thiamin, riboflavin, and Vitamin D. This triumph of technology over nature no longer supplies usable sulfur, has lost virtually all of its zinc, no longer contains Vitamin $B_{6}$, is no longer a source of Vitamin A (an important anticancer factor), and is bankrupt in the trace minerals and other nutrients (which the baby chick needs as we do). The amputated egg yolks wind up in-you guessed it-pet foods, cosmetics, and some bakery products. A short description of this egg substitute: it has lost the antioxidants which help to protect you against cancer. It is a striking example of the blindness of food technology to the nutritional needs of the public it exploits. ${ }^{36}$

Michael Perelman has discussed the final livestock food product.

At first, livestock men complained about the value of hybrid corn as a feed, but this complaint is rarely heard now, because feed today is supplemented with heavy doses of fish protein. Most of this comes from fish 
caught off the shore of Peru where the people suffer from protein deprivation. The U.S. imports enough fish protein to eliminate one-half of the protein deficiency in the entire continent of South America. ${ }^{37}$

It is impossible even to consider providing nutrition to the world population with current technology. An alternative is needed. "Imagine the absurdity of attempting" to suggest that the only alternative to the current situation is to rely "solely on hunting and gathering."38

\section{Appropriate Technology Advocates}

The argument De Gregori uses against appropriate technology advocates is to redefine their position. After referring to them as being of a utopian bent, 39 he says: "They call for an 'appropriate technology' without specifying the criteria of appropriateness.... One of the arguments for small-scale or appropriate (to use the term that begs the question) technology is that it is self-sustaining." 40 Those statements are inconsistent with the extensive criteria those advocates provide. ${ }^{41} \mathrm{E}$. F. Schumacher's book, Small Is Beautiful, for example, explains one criterion after another regarding technological appropriateness. To mention a few, technology should be labor intensive, its value should not be measured in pecuniary terms, it should use renewable energy resources, it should not destroy land and water, and it should not be so large and concentrated as to create monopoly power or be too expensive to be purchased by small producers. ${ }^{42}$ This author also disagrees with many of Schumacher's criteria, but they are very well specified.

De Gregori says that "the very title of E. F. Schumacher's famous book, Small Is Beautiful: Economics as if People Mattered, reflects both an ethical and technological bias." ${ }^{* 3}$ Schumacher makes this point throughout his book. Schumacher, as is De Gregori in his own work, ${ }^{44}$ is forthright about not seeking ethics free analysis.

The appropriate technology proponents have participated in field studies, have succeeded in real world situations with their technology, and have provided vivid real world examples in their writings. De Gregori's article provides none of the latter. It does offer a hypothetical big dam example: "One can conceive of an irrigation scheme with a large dam and modern generators creating electricity. The electricity could provide power for factories or for small pump houses. The water might be used on land where the farmers are using a so-called appropriate technology slightly more efficient than their previous tools. ${ }^{45}$ "Where does such a situation 
exist? The Colorado River certainly is not an example. ${ }^{46}$ It illustrates the results of big dam technology which did not consider holistic consequences. The large dams have invalidated the small technology of steamboats and obliterated the river itself, thereby destroying farming and the fishing industry which were dependent upon it. The system of big dams has destroyed homes and farms, salted and silted farmland, created erosion, destroyed the fish population by lowering the water temperature, destroyed spectacular natural scenery, and has probably created unsustainable population concentrations in Colorado, California, and Arizona. They are probably unsustainable because the Colorado River dams destroy millions of acre-feet of water each year through evaporation and absorption by the stone surrounding the dams. These same kinds of results, plus social fragmentation and increased disease, have been the consequence of the big dams of Africa. ${ }^{47}$

\section{Teleological Tautology}

Instead of citing real examples, De Gregori accomplishes his own goal by the use of a teleological tautology. It is teleological in that it sets out with the end in view of making the case to "liberate [to use the term that begs the question] technology." 48 Therefore, technology need not be related to or judged by any external criteria of appropriateness. He says that "technology understood as problem solving carries its own concept of appropriateness." 49 This privileged status for technology allows him, in another article, to say that "if technology is 'destroying' resources, the solution is more technology." "ळo

The teleological goal is accomplished by the use of a thinly veiled tautology in which development is defined as the use of modern technology, which is defined as the dynamic force for economic change, which is defined as development, which is defined as the use of modern technology, and so forth. ${ }^{51}$ In this manner he can conclude that countries independent of modern technology "will find themselves pursuing less than optimal [without specifying the criteria of optimal] strategies for the use of technologies for development." ${ }_{2}$ Why? By definition! "The most efficient [to use the term that begs the question] use of technology for rapid development" is the one which makes the country more dependent on and vulnerable to modern technology. ${ }^{53}$

De Gregori seeks to justify the first tautology by offering a second which is labeled institutional theory. Since the first left us with a requirement of interdependence, and the concomitant stigma of vulnerability, the 
second is necessary to provide the prescriptive value theory legitimizing the requirement. The prescription is necessary in order to show that "there should be no stigma attached to technological borrowing" of modern technology. ${ }^{54}$ Why not? His explanation is that "technology is universal in the sense that all humans have and use technology in some form. It is particular in that a complement of tools, techniques, and machines is adapted to the particular needs of those who are using them. But however particular, they are still basically derivative from this universal process of tool using" (emphasis added).$^{55}$ This says that technology is universal because people use it in their particular milieu. Why do they? Because technology is universal. An impeccable tautology. Note that in addition "universal process" is substituted for "universal." In order to make the point that the technology of all couritries ought to be interdependent, it is necessary to demonstrate that they are involved in the same process. This is accomplished by simply interchanging the terms. This confuses the universality of a practice with a universal process. It is well known that all people use technology. That does not make it a universal process. For anything to be a process the elements must be linked together and influence each other in a common system. We know, for example, that the technology of the Tasaday is not involved in an interdependent process with the technology of the German steel producers. Even when technology does have crosscultural linkage, as it often does, or is the result of cross-cultural borrowing, as it often is, criteria must still be established to define the degree of dependency and to assess whether and how it should be linked.

\section{Ayres's Institutional Theory}

In Ayres's view, it was the universality of the way technology worked (that is, a sharp knife cuts in all societies) and the continuum of the tool combination principle from which we can derive a cross-cultural locus of value. He said: "It is the technological continuum which is ... the locus of value." ${ }^{8 \beta}$ For Ayres, an internationally linked process or international dependency and vulnerability were not necessary. The character of technology could be found within all societies: "Every community has owed its existence to its inheritance of tools and apparatus, the 'know-how' which is a function of the tools." ${ }^{\prime \prime}$ Note that he said every. He did not say all communities interdependent as De Gregori says. The truth proposition for Ayres was that tools came about due to the same combining continuum in all societies, they worked the same in all societies, and they could be instrumentally verified in all societies. The issue here is not whether one 
agrees with Ayres's value theory. The issue is that Ayres cannot be called upon to provide the value base for De Gregori's prescription.

F. Gregory Hayden

The author is Associate Professor of Economics, University of Nebraska, Lincoln.

\section{Notes}

1. Thomas R. De Gregori, "Technology and Economic Dependency: An Institutional Assessment," Journal of Economic Issues 12 (June 1978): 467-76.

2. Ibid., p. 467.

3. F. Ray Marshall, Rural Workers in Rural Labor Markets (Salt Lake: Olympus Publishing Co., 1974), p. 31.

4. LeRoy Quavie and Luther Tweeten, "Policies, 1930-1970," in Size, Structure, and Future of Farms, edited by A. Gordon Ball and Earl O. Heady (Ames: Iowa State University Press, 1972), p. 37; and General Accounting Office, Changing Character and Structure of American Agriculture: An Overview (Washington, D.C.: the Office, 1978), p. 88.

5. Varden Fuller and Willem von Vuuren, "Farm Labor and Farm Markets," in Size, edited by Ball and Heady, pp. 144-70.

6. Ibid., p. 147.

7. Earl O. Heady and Larry R. Whiting, Externalities in the Transformation of Agriculture: Distribution of Benefits and Costs from Development (Ames: Iowa State University Press, 1975), pp. vii-viii.

8. F. Ray Marshall and Lamond Godwin, Cooperatives and Rural Poverty in the South (Baltimore: Johns Hopkins Press, 1971), p. 25.

9. Philip M. Raup, "Societal Goals in Farm Size," in Size, edited by Ball and Heady, p. 15; and Ron Larsen, "Bergland Talks about Irrigation," Irrigation Age 13 (February 1979): 6-10.

10. General Accounting Office, Changing Character, pp. 122 and 129.

11. Richard D. Rodefeld, "The Causes of Change in Farm Technology, Size, and Organizational Structure," in Change in Rural America: Causes, Consequences, and Alternatives, edited by Richard D. Rodefeld and others (Saint Louis: C. V. Mosby, 1978), p. 219.

12. Congressional Budget Office, Public Policy and the Changing Structure of American Agriculture: An Overview (Washington, D.C.: General Accounting Office, 1978), p. xii; and entire issue of New Land Review (Winter 1979).

13. Marshall, Rural Workers, p. 34. Also see Jim Hightower, Eat Your Heart Out: How Food Profiteers Victimize the Consumer (New York: Vintage Books, 1976), pp. 189-217.

14. Earl O. Heady and Steven T. Sonka, Farm-Size, Structure and Off-Farm Income and Employment Generation in the North Central Region (Ames: North Central Regional Center for Rural Development, 1975), p. 1; and General Accounting Office, Changing Character, p. 88. 
15. Marshall, Rural Workers, p. 23; and Jonathan P. Sher, "What's Next? A Research and Action Agenda for Rural Education," in Education in Rural America: A Reassessment of Conventional Wisdom, edited by Jonathan P. Sher (Boulder: Westview Press, 1977), pp. 271-90.

16. Varden Fuller, Rural Worker Adjustment to Urban Life: An Assessment of the Research (Washington, D.C.: National Manpower Policy Task Force, 1970), pp. 1-2.

17. De Gregori, "Technology," p. 467.

18. Ibid.

19. Ibid.

20. R. L. McNamara, "Impact of Rural Migration on the City" in Rural America, edited by Rodefeld et al., pp. 88-91.

21. See above.

22. Alan Bible, "Impact of Corporation Farming on Small Business," in Rural America, edited by Rodefeld et al., pp. 207-208; Roger Blobaum, "The Loss of Agricultural Land," in ibid., pp. 389-402; and General Accounting Office, Changing Character, p. 147.

23. Heady and Whiting, Externalities, p. viii.

24. George Sibley, "The Desert Empire," Harpers 255 (October 1977) : 6568.

25. Blobaum, “Agricultural Land," pp. 389-402.

26. Ibid., p. 391.

27. See William Lockeretz et al., A Comparison of the Production, Economic Returns, and Energy Intensiveness of Corn Belt Farmers that Do and Do Not Use Inorganic Fertilizers and Pesticides (St. Louis: Center for the Biology of Natural Systems, 1975); and David Pimentel et al., "Food Production and the Energy Crisis," Science 182 (2 November 1973): 443-45.

28. Gail Bronson, "Chemical Concern: Worries are Growing Over Male Infertility Because of Job Hazards," Wall Street Journal, 26 January 1978, pp. 1 and 23, and "Bitter Reaction: Issue of Fetal Damage Stirs Women Workers at Chemical Plants," Wall Street Journal, 9 February 1979, pp. 1 and 19.

29. Harrison Welford, "Agribusiness: Overkill on the Farm," in Rural America, edited by Rodefeld et al., pp. 53-58.

30. Michael J. Perelman, "Farming with Petroleum," in ibid., p. 49.

31. See Paavo Airola, How to Get Well (Phoenix: Health Plus Publishers, 1976); and Nutrition Search, Inc., Nutrition Almanac (New York: McGraw-Hill, 1975).

32. This statement is based on the reviewer's own experience with the international livestock and grain transportation system.

33. Frances M. Lappé and Joseph Collins, Food First: Beyond the Myth of Scarcity (Boston: Houghton-Mifflin, 1977).

34. Hightower, Eat Your Heart Out.

35. Carlton Fredericks, Breast Cancer: A Nutritional Approach (New York: Grosset \& Dunlap, 1977).

36. Ibid., p. 154.

37. Perelman, "Farming," p. 48. 
38. De Gregori, “Technology,” p. 467.

39. Ibid., p. 470.

40. Ibid,, p. 471.

41. See, for example, Marilyn Carr, Economically Appropriate Technologies for Developing Countries: An Annotated Bibliography (London: Intermediate Technology Publications, 1976); and Amory Lovins, "Energy Strategy: The Road Not Taken?" Foreign Affairs 55 (October 1976): 63-96, and Soft Energy Paths: Toward a Durable Peace (New York: Penguin Books, 1977).

42. E. F. Schumacher, Small Is Beautiful: Economics as if People Mattered (New York: Harper \& Row, 1975), pp. 54-56; 20 and 43-47; 14-16, $18-20$, and $60 ; 102-17$; and $33-36$ and 66 .

43. De Gregori, "Technology," p. 470.

44. See De Gregori's excellent article, "Market Morality: Robert Nozick and the Question of Economic Justice," American Journal of Economics and Sociology 38 (January 1979) : 17-30.

45. De Gregori, "Technology," p. 474.

46. "The Colorado River: Conservation and Reclamation," produced by Simon Campbell-Jones (Boston: WGBH-NOVA Series, 1976); the entire issue of Natural Resources Journal 15 (January 1975); and William E. Blundell, "Stormy Stream: Colorado River, Vital to Southwest, Travels Ever-Rockier Course," Wall Street Journal, 12 February 1979, pp. 1 and 25.

47. Donald Heyneman, "Dams and Disease," Human Nature 2 (February 1979) : 50-57.

48. De Gregori, "Technology," p. 473.

49. Ibid., p. 474.

50. Thomas R. De Gregori, "Technology and Ceremonial Behavior: Aspects of Institutionalism," Journal of Economic Issues 11 (December 1977): 867.

51. De Gregori, "Technology," pp. 468 and 473.

52. Ibid., p. 475.

53. Ibid., pp. 475 and 476.

54. Ibid., p. 474.

55. Ibid., p. 473.

56. Clarence E. Ayres, The Theory of Economic Progress: A Study of the Fundamentals of Economic Development and Cultural Change (New York: Schocken Books, 1962), p. 220.

57. Ibid., p. 222.

\section{Instrumental Criteria for Assessing Technology : An Affirmation by Way of a Reply}

The teleological tautology (whatever that may be) is purely a figment of Gregory Hayden's imagination. He quotes me: "Technology under- 
stood as problem solving carries its own concept of appropriateness."1 The technology of a tool lies in its ability to solve a problem. This is not a "privileged status"; in the same sentence from which the above quotation was taken, I argue for the importance of problem definition. "Viewing technology as problem solving makes the definition of the problem a vital element in the specification of any tool as being technological for a specific objective." Need we add that specification is an individual and societal task. I trust that this also addresses Hayden's concern about a supposed technological determinism in my article.

The "thinly veiled tautology" of technology-development-technology is referenced to page 468 (and page 473), on which the reasons for technological borrowing were given, that is, to improve levels of living, survival, and so forth. ${ }^{3}$ Hayden may not agree with these, but he cannot deny that they are there in the text, while the alleged completion of the circular reasoning is not. Similarly, I am not entirely uncomfortable with his interpretation that "technology is universal because everyone uses it in his milieu," although I would have worded it differently. But nowhere do I say that people use technology because it is universal. People use technology because it solves problems as they define them.

Hayden delivers the coup de grace by saying that I justified a concept of interdependent technologies by using Ayres's Institutional Theory. "He did not say all communities are interdependent" (italics are Hayden's). Since Ayres's basic concept of knowledge was dynamic and developmental, normally it would be pointless to argue whether an idea fits the exact letter of his theories or whether it was an evolutionary outgrowth of the spirit of them. Presumably, Ayres would wish us to use his writing to open inquiry rather than close it by appeal to doctrinal purity. However, Hayden has made a claim that must be answered. I mention Clarence Ayres once in reference to "Veblen, Clarence Ayres, and other institutionalists," and that is in a sentence concerned solely with the advance of technology "by the combination and recombination of existing tools and technology." The point being made was that appropriate technology, by the small-scale local criterion I noted and by Hayden's criteria, can cut a people off from the benefits of technological progress that occurs worldwide in a combinational process. Thus, an institutional theory of technology is useful because it points out the potential gains and losses that are involved in the choice of a technology. This is one of the things that theory is supposed to do. It gives us operational questions to ask. The combinational aspect of technology is one that Hayden attests to as being Ayresian. Nowhere else do I refer to Ayres, although I speak of institutional theory. Never mind; Hayden is incorrect on both counts. I did not say Ayres said 
it, but I could have, because he did. In a work cited by Hayden, Ayres refers to the state as a "jurisdictional subdivision of a technologically integrated world." For that matter, I was speaking primarily of interdependence between countries and not communities. Hayden should finish a book before he states categorically and unequivocally what is not in it or in the entirety of an author's work.

It is unfortunate that the character of Hayden's critique might obscure the fundamental issue that separates us, a division that reflects a similar schism among those who have thoughts on the subject. Namely, it concerns our attitude toward modern technology (or whatever Hayden chooses to call it-I will not quibble). There have always been people who distrusted the latest technology in their time, but I find it strange that a group calling itself Ayresian and institutionalist takes this position. Each to his own, and let a thousand flowers bloom! If a few simple statements about urban concentration in industrial countries, or about conceivable agricultural schemes having large dams as a component, trigger a polemic against agriculture as it is practiced in industrial countries, and if advocacy of any facet of industrial technology makes one guilty of all the sins that Hayden catalogs, then we can only reasonably conclude that Hayden himself rejects this technology. For if he accepts any part of it, by his own reasoning processes, he would be the legitimate subject of a critique comparable to his own. Similarly, the élan of appropriate technology (or intermediate technology) as an all-encompassing system is predicated upon some supposed failure in existing technologies to come to grips with problems of poor countries and of industrial countries.

Amory Lovins, one of the two appropriate technology advocates cited by Hayden (along with an annotated bibliography), contends that there are two kinds of technology, soft (that is, appropriate, and so forth) and hard, and that we must choose one path of technological development or the other. ${ }^{5}$ Similarly, from Schumacher we learn that in "the subtle system of nature, technology, and in particular the super-technology of the modern world, acts like a foreign body, and there are now numerous signs of rejection." One does not need to "misrepresent" Schumacher to those who have not read his work in order to make him appear not entirely modern or scientific in his perspective on issues. He thinks that a woman's place should be in the home. ${ }^{7} \mathrm{He}$ thinks that unemployment is not a problem in countries such as the United States if it is viewed and attacked from the perspective of the local community or neighborhood. ${ }^{8}$ Hayden has placed himself solidly in this camp. In my article (including one section quoted by Hayden), I advocated the use of all kinds of technologies, including appropriate technology. I even conceded that "it might well be 
that for some countries under present circumstances, the bulk of their effort should be directed toward a basic needs strategy employing smallscale technology." What I argued for was "empirical investigation" and testing, not for a priori assumptions." But this is not good enough for Hayden. He tell us: "It is impossible even to consider providing nutrition to the world population with current technology."

Has "current technology" failed us so badly? If we cannot trust our local supermarket, who can we trust? Hayden's documentation is impressive. Impressive though Hayden's documentation may be, the question is, where is the aggregate evidence? Since Hayden thinks that reference to Ayres's value base is important to our debate, let us note his observation on this point. "Industrial society is the most successful way of life mankind has ever known. Quite literally, we have never had it so good. People eat better, sleep better, live in more comfortable dwellings, get around more and in far better comfort, keep in better repair, and notwithstanding all the manifold dangers of the industrial way of life-live longer than men have ever done before." 10

We can raise the same issue of aggregate implications of the technology that has been used for development in poorer countries. David Morawetz sums up the actual circumstances of development in the last few decades.

In average per capita income the developing countries grew more rapidly between 1950 and $1975-3.4$ percent a year-than either they or the developed countries had done in any comparable period in the past. They thereby exceeded both official goals and private expectations. That this growth was real and not simply statistical artifact may be seen in the progress that occurred simultaneously in various indexes of basic needs. Increases in life expectancy that required a century of economic development in the industrialized countries have been achieved in the developing world in two or three decades. Progress has been made in the world in the eradication of communicable diseases. And the proportion of adults in developing countries who are literate has increased substantially. ${ }^{11}$

This development is not cause for euphoria, despite the fact that it is unprecedented in magnitude. For some, the levels of living are so low that even high rates of per capita growth will leave them in poverty for too long. And there are major problems of distribution. But, as Morawetz and Irma Adelman have noted, distribution is largely a problem of ownership of productive assets (including education), not of the rate of growth, the type of economic system, or of the technology used. ${ }^{12}$ These difficulties and others are hardly grounds for condemning modern technology, or for abandoning it for one that, according to Schumacher, does not yet exist (although the knowledge for it does) ${ }^{13}$ And on the question of distribu- 
tion raised by critics of the use of modern technology in economic development, when we wish to compare countries to models of more equitable distribution, which ones do we use but Sweden or Holland?

Hayden and the appropriate technology people have a strange habit of reversing the truth. Three times Hayden speaks of vulnerability, including a country's being "vulnerable to modern technology." Which countries of the world are most vulnerable to small changes in rainfall or climatic variables? Which countries are most vulnerable to pestilence or disease? The rich or the poor? And when these areas suffer some disaster, which countries have the means to help-the industrial or the nonindustrial? These rhetorical questions are so obvious that they answer themselves. And it is quite clear that Third World countries would like to be "vulnerable" to modern technology. The call for a New International Economic Order is a recognition of the necessity to try to achieve genuine interdependence (difficult as that may be), since complete self-sufficiency is not a viable alternative.

If Hayden is charging me with believing that, with all its faults, the industrial way of life is the best that humans have ever created, then I plead guilty as charged. However, I would argue that we can use our technology and develop new technology to improve the quality of life even further in developed and underdeveloped countries, including solving some of the ills referred to by Hayden. Modern sophisticated science and technology, from satellites to plant genetics, offer great potential for continuing and accelerating development. That does not mean that I advocate sophisticated technology exclusively (and my article is clear on that point). The more the technologies that are available, the greater the range of choices. What the sections on appropriate technology in my article argued against were $a$ priori theories of technology that beg the question by giving answers to all questions before they are asked, and that seek to eliminate totally other forms of technology from consideration for problem solving. An earlier draft of this comment contained specific arguments in response to Hayden. These are issues that need to be debated in detail in the $J E I$ and other journals or forums.

My article opposes economic and technological dependency, naïve free market beliefs, and autarchic theories of small-scale technologies. It advocates that democracy and education, institutional economic theory, and empirical investigation (meaning the scientific method) be used in the process of choosing technologies. After trying to cut through Hayden's jargon about teleological tautologies, and so forth, I am still at a loss to see what his fuss is about, unless he does actually believe that peoples of the world can do without modern science and technology (not only in the 
sense of what exists but also what is continually coming into being). If that is the case, then I would have to say, respectfully, that he is wrong and that it is unfortunate that space does not permit us to have a detailed empirical debate (with "substantiating evidence," as he calls it), because the issues involved here are at the heart of the development process. I am grateful to Hayden for the opportunity of joining some of them here.

Thomas R. De Gregori

The author is Professor of Economics, University of Houston, Houston, Texas.

\section{Notes}

1. Thomas R. De Gregori, "Technology and Economic Dependency," Journal of Economic Issues 12 (June 1978) : 474.

2. Thomas R. De Gregori, "Technology and Ceremonial Behavior: Aspects of Institutionalism," Journal of Economic Issues 11 (December 1977): 866. This article also deals with the question of technology and the creation of resources to which Hayden alludes.

3. De Gregori, "Technology and Economic Dependency," p. 478.

4. C. E. Ayres, The Theory of Economic Progress (Chapel Hill: University of North Carolina Press, 1944), p. 290.

5. Amory B. Lovins, "Energy Strategy-The Road Not Taken," Foreign Affairs 55 (October 1976) : 65-96.

6. E. F. Schumacher, Small Is Beautiful: Economics as If People Mattered (New York: Harper \& Row, 1973), p. 139.

7. Ibid., pp. 53-54.

8. E. F. Schumacher, "Taking the Scare Out of Scarcity," Psychology Today 11 (September 1976) : 16. E. F. Schumacher, $A$ Guide for the Perplexed (New York: Harper \& Row, 1977), is chock full of the occult.

9. De Gregori, "Technology and Economic Dependency," p. 474.

10. C. E. Ayres, Toward a Reasonable Society: The Values of Industrial Civilization (Austin: Uuniversity of Texas Press, 1961), p. 13. The purpose in writing the book was to argue and justify that industrial society was not at a "dead end" and that science was not "spiritually sterile" (p. 5).

11. David Morawetz, Twenty-five Years of Economic Development 19501975 (Washington, D.C.: World Bank, 1977), p. 67. See also his article, same title, in Finance and Development 14 (September 1977): 10-13. On population, see also Rati Ram and Theodore W. Schultz, "Life Span, Health, Savings, and Productivity," Economic Development and Cultural Change 27 (April 1979) : 399-421; and the entire issue of Population Reports, Series M., no. 3 (July 1979).

12. Morawetz, Twenty-five Years, pp. 71-72; and Irma Adelman, "A Theory of Development Strategy for Equitable Growth in Developing Countries," in Research in Economic Anthropology, A Research Annual, edited by 
George Dalton (Greenwich, Ct.: JAI Press, 1979), vol. 2, pp. 247-67. It is, after all, Irma Adelman's statistical work ( along with that of Cynthia Taft Morris) that is probably the most frequently cited research on the problem of inequality in developing areas. See, for example, Irma Adelman and Cynthia Taft Morris, Economic Growth and Social Equity in Developing Countries (Stanford, Calif.: Stanford University Press, 1973).

13. Schumacher, Small Is Beautiful, p. 146. 